Pakistan Journal of Nutrition 15 (1): 28-32, 2016

ISSN 1680-5194

(C) Asian Network for Scientific Information, 2016

\title{
Characteristics of Ettawa Crossbred Dairy Goat Rumen Fluid and Digestibility of Palm Oil Industry By-Products
}

\author{
Arief $^{1}$, N. Jamarun ${ }^{1}$ and B. Satria ${ }^{2}$ \\ ${ }^{1}$ Faculty of Animal Science, Andalas University, West Sumatera, Indonesia \\ ${ }^{2}$ Faculty of Agriculture, Andalas University, West Sumatera, Indonesia
}

\begin{abstract}
The in-vitro characteristics of the rumen fluid of ettawa crossbred dairy goats was analyzed to determine the digestibility of range of feeds based on palm oil industry by-products. The research used completely randomized design (CRD) with 5 different ratios of Palm Kernel Cake (PKC) and Palm Oil Sludge (POS) as follows: A; (10\% PKC+50\% POS), B; (20\% PKC+40\% POS); C (30\% PKC+30\% POS; D (40\% $\mathrm{PKC}+20 \% \mathrm{POS}), \mathrm{E} ;(50 \% \mathrm{PKC}+10 \% \mathrm{POS})$. The characteristics of rumen fluid that were measured were $\mathrm{pH}$, Volatile Fatty Acid (VFA) and NH3-N and digestibility of Dry Materials (DDM) and Organic Materials (DOM) in-vitro. The in-vitro study was performed according to the method of Tilley and Terry (1983). The results showed that the measured characteristics of the rumen fluid were within normal limits with $\mathrm{pH}$ 6.87-6.94, VFA 102.40-133.62 mM and NH3-N 9:00-9.91 mM. The digestibility of Dry Matter (DDM) ranged from 40.13 to $45.52 \%$ and the digestibility of Organic Materials (DOM) ranged from 38.94 to $44.56 \%$. Most of the parameters depended significantly on the ratio of PKC and POS.
\end{abstract}

Key words: Rumen in-vitro, digestibility, Etawa, by-products of palm oil industry

\section{INTRODUCTION}

One of the factors affecting the level of livestock productivity is feed. Adequate availability and quality of food with assured continuity is required to sustain production levels. Also the largest cost in the process of farm production is the cost of feed. Some studies show that feed costs may reach $60-70 \%$ of the cost of production. Obtaining feed is becoming increasingly difficult because many ingredients such as corn, soybean meal and fish meal are imported. In the long term, alternative feed ingredients with adequate availability and quality need to be found to reduce dependence on the expensive imported feed materials and meet projected increasing demand. One possible local feed alternative is the by-products of the palm oil industry.

Indonesia is the largest palm oil producer in the world with Crude Palm Oil (CPO) production of 27 million tonnes/year (Wihardandi, 2012). The total area of oil palm plantations is 11.5 million hectares (Direktorat Jendral Perkebunan, 2012). Each hectare of oil palm plantation produces around 16 tonnes of fresh fruit bunches (FFB) from which 4 tonnes of CPO is extracted (Liwang, 2003). The by-product from each tonne of FFB include $294 \mathrm{~kg}$ of sludge and $35 \mathrm{~kg}$ palm kernel cake. Palm kernel cake (PKC) and palm oil sludge (POS) which has potential as animal feed alternatives (Carvalo et al., 2005; Mathius, 2004).

Unfortunately these by-products of palm oil industry have low nutritional values especially with regard to protein content and digestibility and some components are unpalatable and potentially polluting (Hanafi, 2004). The cell wall of FFB is covered with complex crystalline silica, has a high degree of lignification and contains cellulose structures that are difficult to digest (Devendra, 1990), hence the utilization still not optimal (Ningrat et al., 2013). One way to improve the digestibility of fibrous feed is to use probiotics. The use of probiotics improves dry matter intake, digestibility of dry matter and organic matter resulting in better productivity of livestock (Winugroho et al., 2000).

The vegetation that naturally grows alongside oil palm in plantation also has potential as a source of forage for livestock (Mathews, 2008). Chen et al. (1991) states that this vegetation can produce 2.6-2.8 tonne of dry matter/ha/year. Assuming that $60 \%$ of the total area of Indonesian plantation are at a productive stage the byproducts from the palm oil industry along with this vegetation would be sufficient to feed the current number of cattle in Indonesia (Mathius, 2008).

Another form of livestock other than dairy cattle that has potential for milk production in Indonesia is the Crossbreed Etawa (CE) Goat. The CE goat can adapt to most environments in Indonesia, is dual-purpose (meat and milk), has good reproductive properties and produces milk with better nutritional properties as the fat globules are smaller resulting in easier absorption. CE goat's milk has a higher content of fluorine (10-100 times) than cow milk's which provides a natural antiseptic that can suppress the growth of pathogenic 
bacteria in the body (Damayanti, 2002). Goats milk is also reported to cure various diseases such as asthma and tuberculosis (Mulyanto and Wiryanta, 2002).

The use of by-products of the palm oil industry combined with the naturally growing plantation vegetation as feed is the focus of this study.

The potential to use oil palm plantations as a source for the dairy goat industry is high. Goat are raised in area close to the plantation and integrating these two industries could play a significant role in achieving the national 2020 goal of self sufficiency in food production, particularly milk.

Research was conducted to determine the quality and digestibility of PKC and POS as dairy goat feed using in-vitro testing.

\section{MATERIALS AND METHODS}

PKC and POS were combined in a concentrate with the addition of corn, rice bran and coconut cake which was then fed to dairy goats and followed by in vitro testing. The research objective was to optimize the formulation of this PKC/POS based feed based on measures of rumen fluid characteristics and digestibility.

Research used completely randomized design (CRD) with 5 concentrate feed ratios:

1: Treatment A: $10 \%$ PKC+50\% POS

2: Treatment B: $20 \%$ PKC+40\% POS

3: Treatment C: $30 \% \mathrm{PKC}+30 \%$ POS

4: Treatment D: $40 \%$ PKC+20\% POS

5: Treatment E: $50 \%$ PKC+10\% POS

Formulation, feed composition, nutritional content and ingredients can be seen in Table 1.

Data were analyzed using analysis of Variance (ANOVA) according to Steel and Torrie (1991), while the differences between treatments were tested by Duncan's Multiple Range Test (DMRT).

Parameters measured were (1). Characteristics of rumen fluid ( $\mathrm{pH}$, VFA and $\mathrm{NH} 3$ ) measured by gas chromatography and (2). In-vitro digestibility of nutrients (dry matter digestibility (DMD) and Organic Matter Digestibility (DOM) using the method developed by Tilley and Terry (1969).

\section{RESULTS}

The results of research on the characteristics of in-vitro rumen can be seen in Table 2 .

The results of statistical analysis showed that the $\mathrm{POS} / \mathrm{PKS}$ ratio of the feed did not affect the $\mathrm{pH}$ or the NH3-N concentration or content of the rumen fluid. Volatile fatty acid (VFA) content increased with the percentage of palm kernel cake in the feed.

The results of statistical analysis showed a significant difference $(p<0.05)$ in digestibility between different $\mathrm{POS} / \mathrm{PKS}$ ratios. With a higher proportion of palm kernel cake, both the dry matter and the organic matter were more digestible.

\section{DISCUSSION}

Characteristics of rumen in-vitro: Statistical analysis showed that varying the POS/PKS ratio of the feed had no significant difference $(p>0.05)$ on the $\mathrm{pH}$ of rumen fluid with $\mathrm{pH}$ ranging between 6.87-6.94 for all trials. A range of $\mathrm{pH}$ values between 6-7 is normal and is good for rumen microbial activity (France and Siddon, 1993) while the $\mathrm{pH}$ ideal for fiber digestion is 6.4-6.8. Values obtained in this study are only slightly higher than this optimal range. Near optimal $\mathrm{pH}$ can help bacteria colonize the plant cell wall and can encourage bacterial cellulase activity. Digestion will only be disrupted if the rumen fluid has a pH is below 6 and at $\mathrm{pH} 5$ to 6 , the activity of rumen microbes to digest the feed will be hampered or even stopped (Chanjula et al., 2004). A pH of less than 6.2 will inhibit rumen microbial growth significantly (Orskov and Ryle, 1992). With the observed $\mathrm{pH}$ in the normal range activity of rumen microbes in the digestion process was not compromised.

The average concentration of VFA observed ranged from 102.40 to $133.62 \mathrm{mM}$ which is within the range suggested by previous research (Mc Donald et al., (2002), Preston and Leng (1989). According to Mc Donald et al. (2002), optimal concentration of VFA in rumen fluid for microbial growth is $80-160 \mathrm{mM}$, according to Preston and Leng (1989) the minimal amount of VFA in rumen fluid for microbial survival is 50 $\mathrm{mM}$.

Silalahi (2003) stated that an increase in the number of rumen microbial cells increases the production of VFA so that rumen microbes can thrive resulting in a further increase in availability of VFA which in turn provides further energy for microbial growth. Hartati (1998) pointed out that the VFA production in rumen fluid can also be used as a measure of feed ferment ability as the higher level of ferment ability of a feed material, the greater the VFA produced. The results obtained in this study indicate that the availability of $\mathrm{NH} 3-\mathrm{N}$ in rumen fluid was sufficient for microbes to thrive resulting in good levels of VFA which provides an abundant source of energy for further growth and development of microbes. Sutardi (1987) suggested the optimal concentration of NH3-N in rumen fluid was between 4-12 mM and McDonald et al. (1995) suggesed 6-21 mM. Availability of NH3-N in the rumen fluid in goats fed each of the 5 different POS/PKS ratio feeds in this study ranged between 8.67 and $9.91 \mathrm{mM}$. This is well within both these estimates of the normal range required to support optimum growth and activity of bacteria. Adequate NH3$\mathrm{N}$ in rumen fluid leads to easier degradation of protein feed in the rumen and provide a good balance of energy and nitrogen required by rumen microbes for growth. According to Erwanto et al. (1993) the concentration of $\mathrm{NH} 3-\mathrm{N}$ in rumen fluid also determines the efficiency of microbial protein synthesis which ultimately will affect the fermentation of organic material in the form of volatile 
Pak. J. Nutr., 15 (1): 28-32, 2016

Table 1: Formulation and nutrient content of feed

\begin{tabular}{|c|c|c|c|c|c|}
\hline \multirow[b]{2}{*}{ Feed ingredient } & \multicolumn{5}{|c|}{ - } \\
\hline & A & $\mathrm{B}$ & $\mathrm{C}$ & $\mathrm{D}$ & $E$ \\
\hline Palm kernel cake & 10 & 20 & 30 & 40 & 50 \\
\hline Palm oil sludge & 50 & 40 & 30 & 20 & 10 \\
\hline Corn & 15 & 15 & 15 & 15 & 15 \\
\hline Rice bran & 20 & 20 & 20 & 20 & 20 \\
\hline Coconut meal & 4 & 4 & 4 & 4 & 4 \\
\hline Mineral & 1 & 1 & 1 & 1 & 1 \\
\hline Percentage (\%) & 100 & 100 & 100 & 100 & 100 \\
\hline \multicolumn{6}{|c|}{ Nutrient content (\%) } \\
\hline Crude protein & 11.58 & 12.59 & 12.93 & 14.28 & 14.46 \\
\hline Crude fiber & 8.45 & 10.76 & 9.17 & 8.99 & 8.79 \\
\hline Cellulose & 11.12 & 12.04 & 14.4 & 14.85 & 17.92 \\
\hline Lignin & 18.36 & 15.94 & 13.82 & 10.73 & 10.65 \\
\hline Silica & 5.35 & 4.30 & 3.89 & 3.06 & 1.71 \\
\hline
\end{tabular}

Source: Results of Laboratory Analysis of Ruminant Nutrition, Andalas University (2015)

Table 2: Rumen in-vitro characteristics in goats fed on rations based on Palm oil by-products

\begin{tabular}{llllll}
\hline Rumen in-vitro & - & & & & \\
\hline Characteristics & A & B & C & D & E \\
\hline pH & 6.87 & 6.89 & 6.9 & 6.78 & 6.94 \\
VFA $(m M)$ & $102.40^{\mathrm{a}}$ & $113.64^{\mathrm{b}}$ & $114.89^{\mathrm{b}}$ & $117.39^{\mathrm{b}}$ & $133.62^{\mathrm{c}}$ \\
$\mathrm{NH} 3-\mathrm{N}(\mathrm{mM})$ & 9.33 & 9 & 8.67 & 9.5 & 9.91 \\
\hline
\end{tabular}

Different superscripts on the same line indicate significantly differences in values $(p<0.05)$

Table 3: DMD and DOM palm oil industry by product

\begin{tabular}{llllll}
\hline Digestibility & - & - & - & - & - \\
\hline Dry matter (\%) & $38.94^{\mathrm{a}}$ & $39.61^{\mathrm{a}}$ & $40.22^{\mathrm{a}}$ & $40.49^{\mathrm{a}}$ & $44.55^{\mathrm{b}}$ \\
Organic matter (\%) & $40.29^{\mathrm{a}}$ & $40.13^{\mathrm{a}}$ & $40.82^{\mathrm{a}}$ & $41.09^{\mathrm{a}}$ & $45.52^{\mathrm{b}}$ \\
\hline
\end{tabular}

Different superscripts on the same line indicate significant differences in value $p<0.05$

fatty acid (VFA) as the main energy source in ruminants. Winugroho and Maryati (1999) showed that at concentrations of $\mathrm{NH} 3$ exceeding $12 \mathrm{mM}$, the conversion process of $\mathrm{NH} 3$ to $\mathrm{N}$ is disturbed and if $\mathrm{NH} 3$ is less than $4 \mathrm{mM}$ (conditions of low dietary protein) the process of degradation may also be disrupted.

Digestibility of dry matter (DDM) and digestibility of organic matter (DOM): The data of Table 3 shows that the DDM of the feed ranged between $38.94-44.55 \%$ and the DOM was $40.29-45.52 \%$. The POS/PKS ratio E was the most completely digested (significantly different compared to the other treatments at $\mathrm{p}<0.05)$, with $45.52 \%$ of DOM and $44.55 \%$ of DDM digested. The higher DDM of ratio $E$ was almost certainly due to the higher protein content of the material which resulted in greater availability of $\mathrm{NH} 3$ stimulating higher rumen microbe activity. Bamualim (1988) explained that the availability of adequate protein will lead to the increasing activities and growth of microorganisms resulting in more complete digestion. Oktarina et al. (2004) demonstrated that increased protein content of feed increased the rate of growth of microbes and higher rumen microbial population results in a better digestion of food. Higher protein content therefore raises the total digestible nutrient value of the feed. Digestibility of dry matter was closely linked to Total Digestible Nutrient (TDN). The higher protein content of ratio $\mathrm{E}$ positively impacts the TDN and the availability of energy that can be utilized by rumen microbes because TDN is the amount of organic matter that can be used as energy by both the rumen microbes and the livestock in the form of ATP (Tillman et al., 1998). The superior DDM and DOM of ratio $E$ could be do to the lower content of relatively indigestible lignin and silica in the $E$ ratio compare to the other ratios. than the other treatments. Silica is too hard to be fermented by rumen microbes.

lluyemi et al. (2006) concluded that even though the nutrient content of the palm oil industry by-products was high, its value as animal feed was low due to the high crude fiber and lignin, particularly in the oil sludge, resulting in low palatability and digestibility. DOM depends on the balance of nutrients. Van Soest et al. (1994) stated that the ability to digest the feed material was determined by several factors such as the type of livestock, the chemical composition of feed ingredients and feed preparation. The digestibility of a feed was dependent on the nutrients.

DDM and DOM values obtained from this study compare with those found by Astuti (2012) who observed values of 42.76 and $43.55 \%$, respectively but were lower than those obtained by Zain et al. (2009). According to Mukhtaruddin and Liman (2006) DDM and DOM should both be $=60 \%$ of feed.

Data from Table 3 also showed an increase in dry matter digestibility along with an increase of organic matter (significant difference was $p<0.05$ ). It is to be expected that the value of DDM is dependent on the DOM because the largest component of dry matter is organic matter so that when the DDM increased, DOM is also increased. Results of this research was supported by Sutardi (1987) who stated that an increase in the digestibility of dry matter was positively correlated with the increase of organic matter in feed because most of the components of the dry matter were organic matter, therefore factors that affected the level of DDM would also affect the level of DOM in the feed. The relationship between the value of dry matter and organic matter was very close $(r=0.98)$ as the organic matter was a major part of dry matter.

Dry matter contains indigestible ash while the organic matter does not (Fathul and Wajizah, 2009) hence DOM is always higher than DDM. The feed containing higher levels of ash was relatively harder to digest because ash would inhibit the digestion of dry matter. This data demonstrated this DOM is higher than DDM for each PKC/POS ratio trilled.

Feed digestibility and NH3-N content: Higher DDM and DOM indicated an increase of nutrient availability, especially volatile fatty acid (VFA) and NH3 for the growth of microbes that will be used for microbial protein 
synthesis. Suryahadi et al. (1993) stated that DDM and DOM measure how efficiently rumen microbes can utilize the feed and was positively correlated with the animal's ability to utilize the nutrients in the feed. Kurniawati (2007) added that feed with low digestibility values had low degradation so is not able to provide balanced environment for fermentation in the rumen. Rumen microbial growth is low affecting the microbial fermentation in the rumen.

Oktarina et al. (2004) obtained similar results to this study. They also concluded that increased VFA and NH3$\mathrm{N}$ would increase the digestibility of dry matter (DDM) and organic matter (DOM) of feed.

Conclusion: The data demonstrates that ratio E (50\% PKC $+10 \%$ POS) was the best feed tested as indicated by the characteristics of in-vitro rumen and digestibility of nutrients with the results of $\mathrm{pH}$, VFA and $\mathrm{NH}$, respectively 6.94, 133.62 and $9.91 \mathrm{mM}$. While dry matter and organic matter digestibility were 44.55 and $45.52 \%$, respectively.

\section{ACKNOWLEDGMENTS}

The authors are very grateful to Directorate General of Higher Education Department of National Education Republic of Indonesia that funded this experiment through the National Priorities Research Master Plan for the Acceleration and Expansion of Indonesian Economic Development (MP3EI), Contract No. 030/SP2H/PL/DIT. LITABMAS/II/2015, the date February, 5, 2015.

\section{REFERENCES}

Astuti, T., 2012. Potensi dan Teknologi Pemanfaatan Kulit Buah Markisa sebagai Pakan Ternak Ruminansia. Disertasi program Pascasarjana Universitas Andalas, Padang.

Bamualim, A., R.H. Weston, J.P. Hogan and R.M. Murry, 1988. The contribution of Leucaena leucocephala to post ruminal digestible protein for sheep fed tropical pasture hay supplemented with urea and mineral. Proc. Aust. Soc. Anim. Prod., 15: 255.

Carvalo, L.P.F., D.S.P Melo, C.R.M Pereira, M.A.M. Rodrigues, A.R.J. Cabrita and A.J.M. Fonseca, 2005. Chemical composition, in vivo digestibility, $\mathrm{N}$ degradability and enzymatic intestinal digestibility of five protein supplement. Anim. Feed Sci. Technol., 119: 171-178.

Chanjula, P., M. Wanapat, C. Wachirapakorn and P. Rowlinson, 2004. Effect of synchronizing starch sources and protein (NPN) in the rumen on feed intake, rumen microbial fermentation, nutrient utilization and performance of lactatingdairy cows. Asian-Aust. J. Anim. Sci., 17: 1400-1410.

Chen, C.P., 1991. Management of Forage for Animal production under Tree Crops. In Proc Integrated Tree Croping and Small Ruminant Production System. SR-CRSP, Univ. California Davis, USA pp: 10-23.
Damayanti, R., 2002. Susu Kambing Etawah. Balai Penelitian Veteriner, Pusat Penelitian dan Pengembangan Departemen Pertanian. Bogor.

Devendra, C., 1990. Goat Ed. W.J.A. Payne in an Introduction to Animal Husbandry in the Tropics. Fourth Edition. John Willey and Sons. Inc. New York.

Direktorat Jendral Perkebunan, 2012. Buku Statistik Perkebunan, Direktorat Jendral Perkebunan. Departemen Pertanian Republik Indonesia, Jakarta.

Erwanto, T. Sutardi, D. Sastradipradja and M.A. Nur, 1993. Effects of ammoniated zeolit in metabolic parameters of rumen microbes. Indon. J. Trop. Agric., 1: 5-12.

Fathul, F. and dan S. Wajizah, 2009. Penambahan mikromineral $\mathrm{Mn}$ dan $\mathrm{Cu}$ dalam ransum terhadap aktifitas biofermentasi rumen domba secara invitro. J. Ilmu Ternak dan Vet., 15: 9-15.

Hanafi, N.D., 2004. Perlakuan Silase dan Amoniasi Daun Kelapa Sawit Sebagai Bahan Baku Pakan Domba. Fakultas pertanian, Program Studi Produksi Ternak Fakultas Pertanian Universitas Sumatera Utara.

Hartati, E., 1998. Supplemen Minyak Lemuru dan Seng kedalam Ransum yang Mengandung Silase Pod Coklat dan Urea untuk Memacu Pertumbuhan sapi Holstein Jantan. Disertasi Program Pascasarjana Institut Pertanian Bogor.

Iluyemi, F.B., M.M. Hanafi., O. Radziah and M.S. Kamarudin, 2006. Fungal solid state culture of palm kernel cage. Bioresources Technology, 97: 477-482.

Kurniawati, A., 2007. Teknik produksi gas in-vitro untuk evaluasi pakan ternak: volume produksi gas dan kecernaan bahan pakan. J. IIm Appl. Isotop dan Radiasi. Vol 3 No. 1. Juni 2007.

Liwang, T., 2003. Palm oil mill effluent management. Burotrop. Bull., 19: 38.

Mathews, C., 2008. The introduction and establishment of a new leguminous cover plan Mucuna bracteata under oil palm in Malaysia. The Mucuna Network, Golden Hope Plantation Berhard, Tangkak Estate, Malaysia.

Mathius, I.W., Azmi, B.P. Manurung, D.M. Sitompul and E. Prayatomo, 2004. Integrasi Sawit-Sapi: Imbangan pemanfaatan produk samping sebagai bahan dasar pakan. Prosiding. Sistem Integrasi Tanaman-Ternak. Denpasar Juli 2004. HIm, 439446.

Mathius, I.W., 2008. Pengembangan sapi potong berbasis industri kelapa sawit. Pengembangan Inovasi Pertanian, 1: 206-224.

McDonald, P., R. A. Edward., JFD. Greenhalg and CA. Morgan. 1995. Animal Nutrition. 5th Edition, Jhon Willey and Sons Inc, New York. P 157-165 and 221.

Mc Donald, P., R. Edwards and J. Greenhalgh, 2002. Animal Nutrition. Sixth Edition, New York. 
Mukhtaruddin dan Liman, 2006. Penentuan tingkat penggunaan mineral organic untuk memperbaiki bioproses pada rumen kambing secara in-vitro. J. Ilmu-ilmu Pertanian Indon., 8: 132-140.

Mulyanto, R.D. and B.T.W. Wiryanta, 2002. Khasiat dan Manfaat Susu Kambing, Jakarta Agromedia Pustaka.

Ningrat, R.W.S., M. Zain, I. Ryanto and Arief, 2013. Pemanfaatan Limbah Sawit dalam Ransum Ternak Ruminansia untuk Mendukung Percepatan Pencapaian Program Swasembada Daging 2014. Laporan MP3EI.

Oktarina, K., E. Rianto, R. Adiwinarti and dan A. Purnomoadi, 2004. Pemanfaatan protein pada domba ekor tipis jantan yang mendapat pakan penguat dedak padi dengan aras yang berbeda. J. Pengembangan Peternakan Tropis, Spesial edisi Bulan Oktober, Buku I hal, 110-115.

Orskov, E.R. and M. Ryle, 1992. Energy Nutrition In Ruminants. Elsevier Applied Science. London, pp: 13-15.

Preston, T.R. and R.A. Leng, 1989. Matching Ruminant Production System With Available Resources in the Tropics and Sub Tropics. First Printed. International Colour Production. Penambul Books, Armidale, Australia, pp: 49-50.

Silalahi, R.E., 2003. Uji fermentabilitas dan kecernaan in-vitro supplementasi $\mathrm{Zn}$ an organic dan $\mathrm{Zn}$ Organik dalam ransum ruminansia. Skripsi Fakultas Peternakan Institute Pertanian Bogor.

Steel, R.G.D. Torrie, 1991. Prinsip and Prosedur Statistik. Suatu Pendekatan. Biometrik PT. Gramedia Pustaka Utama. Jakarta.

Suryahadi, W.G., Piliang, I. Djuita and Y. Widiastuti, 1993. DNA recombinant technique for production transgenics rumen microbes in order to improve fiber utilization. Indon. J Tropics, 7: 5-9. utardi, 1987. Sapi Perah dan Pemberian Makanannya. Departemen IImu Makanan Ternak. Fakultas Peternakan IPB. Bogor.

Tilley, J.M. and R.A. Terry, 1969. A two stage technique for invitro digestion of forage crops. J. Br. Grassland Soc., 18: 104-111.

Tillman, A.D., H. Hartadi, S. Reksohadiprodjo and S. Lebdosoekotjo, 1998. IImu Makanan Ternak Dasar. Gajahmada University Press. Jokjakarta.

Van Soest, P.J., J.B. Robertson and B.A. Lewis, 1994. Methods for dietary fiber, neutral detergent fiber and non-starch polysaccharides in relation to animal nutrition. J. Dairy Sci., 74: 3583-3597.

Wihardandi, A., 2012. http://www.mongabay.co. $\mathrm{id} / 2012 / 06 / 20 /$ greenpeace-impor-kelapa-sawitindia-hancurkan-hutan-indonesia/.

Winugroho, M. and Maryati, 1999. Kecernaan daun kelapa sawit sebagai pakan ternak ruminansia. Laporan APBN 1998/1999. Balai Penelitian Ternak Puslitbang Peternakan Bogor.

Winugroho, M., Y. Widyastuti, Y. Saefudin and S. Marijati, 2000. Studi penggunaan bubuk kolustrum dan Bioplus untuk produksi susu. Kumpulan Hasil Penelitian APBN TA 2000 Balai Penelitian Ternak Ciawi Bogor.

Zain, M.N. Djamarun and Zulkarnaini, 2009. Effect of phosphor and sulfur supplementation in growing beef cattle diet based on rice straw ammoniated. Dipresentasikan pada seminar International Biotechnology for Better Life. Cairo Egypt, 3-6 November 2009. 